such marine equivalents of the Downtonian. We have already satisfactorily defined and standardized the Ludlovian succession in the Weish Borderland and its boundary with the Downtonian.

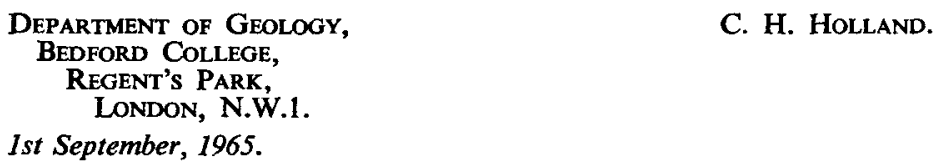

\title{
GRAVITY SLIDE DEPOSITS IN TIMOR AND ECUADOR
}

SIR,-The account of the Bobonaro Scaly Clay by Mr. Audley-Charles (1965) was especially interesting because of the similarity which was suggested throughout, with the Clay Pebble-Beds of Ecuador (Barrington Brown and Baldry, 1925 ; Barrington Brown, 1938; Marchant and Black, 1960).

The uniformity and waxiness of the clay matrix, the characteristic " jigsaw puzzle "type of weathering, the presence but erratic distribution of exotic blocks, the variable thickness of the formation and the evidence for its rapid accumulation-all seem similar. The differences appear to be that the Bobonaro Scaly Clay is varicoloured and contains a greater age-range of exotic material, whereas the Ecuadorian Clay Pebble-Beds is uniformly grey, contains, so far as is known, little exotic material greatly older than itself and, of course, is liberally provided with the characteristic clay pebbles. None of these differences seems to be anything more than one would expect from differences in provenance, especially as the clay pebbles can be explained as lumps which have retained their coherence during sliding.

Mr. Audley-Charles stresses the point that the Bobonaro Scaly Clay is not associated with turbidity deposits in the way that occurs in the Wildflysch of the Swiss Alps. It may be thought that here is another difference from the Clay Pebble-Beds which certainly are associated with turbidity deposits : from the published accounts (op. cit.) it may not be realized that these turbidity deposits are not interbedded with the clay pebble material. This has to be recognized clearly: the turbidity deposits everywhere overlie the Clay Pebble-Beds and rest on their uneven upper surface without mechanical break. It merely seems, then, that in Ecuador typical flysch deposition followed the gravity slide, whereas in Timor the Viqueque Formation which rests unconformably on the Bobonaro Scaly Clay, was presumably not of this nature, though it is not described by Mr. Audley-Charles.

Probably the only reason why the Ecuadorian deposit was not long ago recognized as due to gravity sliding and is still not always accepted as such, is because it is poorly exposed and most of its occurrence has to be deduced from subsurface data. If it was so well exposed as the Bobonaro Scaly Clay evidently is, there could not have been so much argument about its nature, nor would its association with enormous masses of contorted sandstones and clays have been so puzzling and misleading, to the extent that it was originally attributed to fault brecciation.

A further difficulty in discussing the Clay Pebble Bed has always been to find any description of other deposits which seemed to be convincingly similar. This has now been removed by Mr. Audley Charles' account.

Finally, now that continental drift is such a respectable idea even if the details may still be argued, it is worth drawing attention to the considerable similarity between the locations of these two deposits on the unstable edges of continental masses. Most other gravity slide deposits in the Alps, Appenines, Canada, Trinidad, and Venezuela are no longer associated so clearly with the present-day advancing edges of the continents, but Ecuador may be said to be classically placed with the expanding Pacific floor disappearing eastwards under the advancing coast of South America, and it is legitimate to suppose that in the Miocene the situation off the Javan-Timor island arc was quite comparable and that the Indian Ocean floor was expanding northward under 
the arc and bringing Australia to its present position where it tends to obscure a situation probably not essentially different from that on the east side of the Pacific.

\section{REFERENCES}

Audley-Charles, M. G., 1965. A Miocene Gravity Slide Deposit from Eastern Timor. Geol. Mag., 102, 267-276.

BARRINGTON BROWN, C., 1938. On a theory of gravitational sliding applied to the Tertiary of Ancon, Ecuador. Quart. J. geol. Soc. Lond., 94, 359-370.

- and R. A. Baldry, 1925. On the Clay Pebble-Bed of Ancon (Ecuador). Quart. J. geol. Soc. Lond., 81, 454-460.

MarChant, S., and C. D. G. BlacK, 1960. The nature of the Clay Pebble Beds and associated rocks of south-west Ecuador. Quart. J. geoi. Soc. Lond., 115, 317-338.

\section{Arthur CIRCLE,}

S. Marchant.

CANBERRA A.C.T.

10th September, 1964. 